Journal of Financial Management, Markets and Institutions

Vol. 8, No. 1 (2020) 2040002 (31 pages)

(C) The Author $(\mathrm{s})$

DOI: $10.1142 / \mathrm{S} 2282717 \mathrm{X} 20400022$

\title{
RECENT DEVELOPMENTS IN THE FINTECH INDUSTRY
}

\author{
THOMAS J. CHEMMANUR* \\ Finance Department, Fulton Hall 336 \\ Carroll School of Management, Boston College \\ Chestnut Hill, MA 02467, USA \\ chemmanu@bc.edu \\ MICHAEL B. IMERMAN \\ Drucker School of Management \\ Claremont Graduate University \\ Claremont, CA 91711, USA \\ michael.imerman@cgu.edu \\ HARSHIT RAJAIYA \\ Telfer School of Management \\ University of Ottawa \\ 55 Laurier Avenue East, Ottawa, Ontario, K1N 6N5, Canada \\ hrajaiya@uottawa.ca \\ QIANQIAN YU \\ Perella Department of Finance \\ College of Business, Lehigh University \\ Bethlehem, PA 18015, USA \\ qiy617@lehigh.edu
}

Received 18 March 2020

Accepted 29 April 2020

Published 8 July 2020

In this article, we review some recent developments in the field of Financial Technology or "FinTech." We begin with an overview of what FinTech is and why it has become an important growth industry in the financial services area and therefore an important research topic in finance. In the next section, we review some of the academic literature in the FinTech area. In the subsequent section, we characterize the financing of FinTech startups, especially by venture capital firms. In the following section, we characterize innovation by FinTech firms as well as by incumbent financial intermediaries. In the next section, we move on to discuss potential sources of value creation by FinTech start-up firms relative to existing incumbent firms: we conjecture that one source of value creation may arise from FinTech startups being able to provide a superior customer experience relative to incumbent firms in various areas of consumer finance.

*Corresponding author.

This is an Open Access article published by World Scientific Publishing Company. It is distributed under the terms of the Creative Commons Attribution 4.0 (CC BY) License which permits use, distribution and reproduction in any medium, provided the original work is properly cited. 


\title{
T. J. Chemmanur et al.
}

\begin{abstract}
In the following section, we discuss the regulatory environment facing FinTech firms, in their banking as well as in their financial market activities. In the penultimate section, we analyze the buy-versus-build decision facing firms choosing to enter the FinTech sector and discuss the trade-offs that may drive such decisions in practice. We conclude with some remarks about the future directions that may be taken by the FinTech industry.
\end{abstract}

Keywords: FinTech; financial innovation; banking the unbanked; venture capital finance.

JEL Classification: G21, G23, G24, G28

\section{Introduction}

Over the past decade, since the financial crisis brought the global economy to its knees, financial technology startups have swooped in and offered more innovative solutions to problems in the traditional banking, insurance, and asset management areas. This new and burgeoning industry, which has become known as the "FinTech" industry, has been growing at a rapid rate. FinTech, as the name suggests, refers to the use of the latest technology in solving problems in financial services (often relating to customer experience (CX) and insight). In this article, we restrict our definition of FinTech firms to startup firms (including software developers, hardware manufacturers, data analytics firms, mobile technology, and e-commerce platforms) that have entered into space traditionally occupied by intermediaries like banks and other financial institutions. Of course, traditional financial institutions, or the "incumbents" in the financial service industry are also increasingly using technology to serve their customers: banks provide the option of online lending to their customers and venture capitalists (VCs) may use artificial intelligence (AI) to identify start-ups in which to invest. However, for the purposes of this article, we will not include traditional intermediaries as FinTech firms, focusing mainly on start-up firms in the FinTech industry.

The FinTech Ecosystem can broadly be divided into following eight industry segments (see, e.g. Imerman \& Fabozzi 2020): (i) payments and money transfers; (ii) digital banking; (iii) digital wealth managers, including robo-advisors; (iv) capital markets innovations, including algorithmic trading, high-frequency traders, and market analytics; (v) FinTech lending, including P2P and marketplace lenders; (vi) equity crowdfunding; (vii) InsureTech, which refers to innovations in the insurance industry; and (viii) PropTech, which refers to innovations in the property and real estate industry. The emerging technologies that are being used across the above industry segments in FinTech include blockchain and distributed ledger technology (DLT), biometrics, quantum computing, cloud computing, open-source computing and APIs, big data analytics, machine learning (ML) and AI, Internet-of-Things (IoT) technology, and cybersecurity among others.

After the financial crisis, there has been significant growth in the number of new FinTech firms springing up in the United States as well as globally. Many of these FinTech firms have the potential to displace traditional intermediaries by exploiting the economies of scale in data analytics and providing lower cost financial services to 
their customers compared to the incumbents. Furthermore, the increased penetration of smartphones and improvement in internet speed enabled the continuous realtime provision of financial services in the hands of customers through such mobile devices. As we will show, the largest amount of investment in FinTech companies was made in consumer payment, consumer lending, and payment infrastructure. Prominent FinTech firms in these sectors include Prosper, Lending Club, Venmo, and Square among others. This had a direct implication on banks as these small business lending and peer-to-peer (P2P) lending firms competed directly with banks in some cases, while also addressing the needs of previously underserved consumer segments. Incumbent banks responded to the increased competition from FinTech firms by investing in FinTech innovation and in some cases acquiring FinTech firms. A representative example of the latter case is Capital One's acquisition of Wikibuy in 2018. Similarly, several start-ups made forays in the wealth management space leading to growth in robo-advisors in recent years. Again, the incumbents responded with their own robo-advising services. For example, Vanguard, Schwab, and Fidelity now offer robo-advising services to their clients.

The rest of this article is organized as follows. Section 2 reviews some of the academic literature in the FinTech area. Section 3 characterizes the financing of FinTech startups, especially by venture capital firms. Section 4 characterizes innovation by FinTech firms as well as by incumbent financial intermediaries. Section 5 discusses potential sources of value creation by FinTech start-up firms relative to existing incumbent firms. Section 6 discusses the regulatory environment facing FinTech firms, in their banking as well as in their financial market activities. Section 7 analyzes the buy-versus-build decision facing firms choosing to enter the FinTech sector. Section 8 concludes with some remarks about the future directions that may be taken by the FinTech industry.

\section{Related Academic Literature on FinTech}

In the past few years, it has become apparent that recent technological advancements, including using ML and AI to provide financial services, has led to a paradigm shift worthy of serious research. After all, the ways in which consumers conduct their financial business, from paying bills to managing investments to business and consumer banking, are in the process of changing drastically due to these new technologies.

Philippon (2016) provides an important forward-looking perspective on how technological innovation and the growth of FinTech firms are transforming financial services. He argues that FinTech is reducing the cost of access to financial services and is likely to continue. However, he also points out the new risks and regulatory challenges that FinTech presents. A useful review article by Thakor (2019) specifically analyzes how FinTech innovation may fit in with traditional banking theory. He argues that FinTech innovations may result in lower search costs and verification costs, cheaper and more secure information transmission, and will continue to have a 


\section{T. J. Chemmanur et al.}

disintermediating effect on financial services (i.e. reduced need for traditional intermediaries due to the development of new technologies).

Recently, researchers have done some significant work on consumer lending, especially P2P lending. Using data from Prosper, a leading P2P lending firm, Duarte et al. (2012) show that appearance-based impressions affect financial transactions. Using the assessments of photographs of borrowers on the Prosper platform by 25 independent raters, the above authors show that borrowers who appear more trustworthy have higher probabilities of getting a loan. Tang (2019) shows that P2P lending firms act as substitutes of banks in serving infra-marginal bank borrowers and small borrowers. Vallee \& Zeng (2019) use a theoretical model to study the trade-off between screening by sophisticated investors versus adverse selection problems faced by unsophisticated investors in the context of P2P lending platforms. Their model predicts that, as a lending platform develops, it increases screening intensity but reduces information provision to outsiders. Using investor-level data, they find that sophisticated investors outperform unsophisticated investors, and this outperformance shrinks with a reduction in information provision by platforms. Hertzberg et al. (2018) make use of a natural experiment by LendingClub, one of the first P2P lending firms, and show that more borrowers prefer long-term loans over short-term loans, while those who prefer short-term loans default less. They compare two observationally equivalent groups, one of which could only take 36-months loans, while the other group could take either a 36-month or a 60-month loan, to arrive at the above conclusion. Jagtiani \& Lemieux (2019) show that the correlation between Lending Club rating grades and FICO scores have declined over time. However, they find that these rating grades perform well in predicting defaults and conclude that alternative sources of data (other than FICO scores) help to serve financially underserved consumers.

To the extent that FinTech represents nonfinancial (technology) companies providing services that were traditionally provided by banks and other financial institutions, combined with the fact that significant growth in FinTech began in earnest only after the Financial Crisis, it is natural to think of the similarities and differences between FinTech lenders and "shadow banks." Buchak et al. (2018) study these questions in the context of mortgage lending. They show that both FinTech lending and shadow bank lending in this space have grown between 2007 and 2015 . The major difference is that FinTech lending growth seems to result from using alternative information to set rates and online origination of loans (which reduces both the cost and the time of origination), whereas the shadow banks' growth occurred mostly in geographic and socioeconomic areas that were hardest hit by increased regulation in the post-crisis era. By analyzing FinTech lenders in the U.S. mortgage lending sector, Fuster et al. (2019) show that controlling for observable characteristics, FinTech lenders process applications at a $20 \%$ faster rate compared to other lenders. Further, they show that this faster processing does not come at the cost of higher default. 
There has also been significant literature pertaining to the application of blockchain technology in finance. Biais et al. (2019) discuss the coordination problems among blockchain miners. They argue that although mining the longest chain is the intended equilibrium, there can be multiple equilibria with "forking." a They posit that forking maybe caused by information delays or software upgrades. Chiu \& Koeppl (2019) discuss issues associated with blockchain forking in the context of settlement of asset trading. They argue that, on one hand, the benefit of blockchainbased settlement technology is a faster and more flexible settlement, but on the other hand, there is the scope of tampering where participants may intentionally fork the chain to avoid trading losses. Cong \& He (2019) discuss tension in the usage of blockchain-based smart contracts. They argue that while decentralized contracts and tamper-proof algorithms will expand contract space and enhance contract efficiency, the process of reaching decentralized consensus will change the information environment on the blockchain, promote collusion, and may lead to welfare reduction.

Foley et al. (2019) discuss the dark side of bitcoin and cryptocurrency. They argue that cryptocurrency is among the largest unregulated markets and document that around $46 \%$ of bitcoin transactions (equivalent to around $\$ 76$ billion) is in illegal activities. They find that cryptocurrencies are enabling "black e-commerce." However, they note that the techniques developed in their paper may be used for cryptocurrency surveillance. Griffin \& Shams (2019) find that purchases with Tether, a digital currency pegged to U.S. dollar, are timed following market downturns. By mapping the blockchains of Bitcoin and Tether, they find that one large player on Bitfinex, a cryptocurrency exchange, is purchasing large amounts of Bitcoin after the printing of Tether (increase in supply) as prices are falling. Their evidence supports a supply-based story of inflation of cryptocurrency prices.

There has also been recent work on the disruption of FinTech to investments and wealth management. D'Acunto et al. (2019) study robo-advising and find that adopters of robo-advising are similar to nonadopters in terms of demographics and prior interaction with human advisors. They also find that adopters display a decline in major behavioral biases: disposition effect, trend-chasing, and rank effect. Using data from the largest U.S. robo-advisor, Vanguard's Personal Advisory Services (PAS), Rossi \& Utkus (2019) find that clients with little investment experience as well as clients with large cash holdings and high trading volume benefit the most from robo-advising.

As FinTech is, by definition, an interdisciplinary area, there has also been researched by scholars from fields other than finance studying the impact of technological innovation on financial services provision. One example is the review article by Gomber et al. (2018), which looks at FinTech innovation and disruption from an

a "Forking" in the blockchain arises from two miners working on the same block simultaneously and publishing the new block at the same time (Neudecker \& Hartenstein 2019) or when new rules on the decentralized network are applied (Abadi \& Brunnermeier 2018) 


\section{T. J. Chemmanur et al.}

information systems (IS) perspective. Another article is by Arner et al. (2015), which considers legal and regulatory issues facing FinTech firms. They argue that the challenge for the regulators is to come up with a regulatory system which is flexible enough to encourage innovation but transparent enough to preserve the confidence of investors, customers, and the market.

\section{Venture Financing of Start-up Firms in the FinTech Industry}

The previous section illustrates how interest and excitement around FinTech have grown rapidly in recent years from academics. However, investors have been increasingly excited about FinTech for even longer. To examine the patterns in funding for FinTech companies over time, we use data from the Venture Scanner database. Venture Scanner collects detailed data on funding rounds and exits for startup companies mostly in the technology sector. The data are arranged in sector verticals with drilldowns going deeper into subcategories within the taxonomy. For this paper, we focus on the "FinTech" sector which includes 16 subcategories and 3229 companies as of January 2020.

Information on Venture Scanner is sourced from a wide variety of application programming interfaces (APIs) (including the API of AngelList, which is a database covering over 800,000 startup companies), web scraping of media articles, and more. Venture Scanner then uses proprietary clustering and matching algorithms to populate the database. The dataset comprises startups founded as early as the 1980s, although the number of startups seems to pick up substantially in the period of 19992000. Specifically, a substantial number of FinTech firms were founded in or after 2014.

Figure 1 shows an infographic named "FinTech Sector Map" from Venture Scanner's website, which displays the different subcategories within the FinTech sector with representative companies in the Venture Scanner database. Table 1 presents data on the number of countries from which the startups originate, the number of startups, the number of investors making investment in the startups, and the total amount of capital raised for each subcategory.

We can see from Table 1 that the most globally diverse subcategories are in the payments space: specifically, Consumer Payments, Payments Backend and Infrastructure, and Point-of-Sale (POS) Payments. The subcategory of Consumer Payments has startups from 42 different countries, including the Israeli FinTech company MyCheck, a leading payment and integration technology provider to hospitality industry. The subcategory of Payments Backend and Infrastructure has startups hailing from 41 different countries, including companies like Stripe based in the United States and a large number of companies based in Europe and Asia, as payments technology startups have been thriving for years in Europe and Asia. The subcategory of POS Payments includes startups from 38 different countries. A representative example within this category would be the Swedish company, iZettle, 


\begin{tabular}{|c|c|c|c|c|c|}
\hline 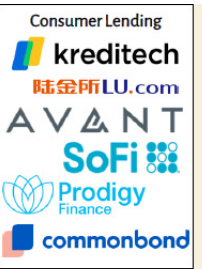 & $\begin{array}{l}\text { BOND STREET } \\
\text { (1) lendinvest } \\
\text { QBlueVine } \\
\text { Af Funding } \\
\text { CArcle } \\
\text { CAN CAPITAL }\end{array}$ & $\begin{array}{l}\text { Personal Finance } \\
\text { credit karma } \\
\text { neyber } \\
\text { 捍照 } 10 \text { digit } \\
\text { personal } \\
\text { CAPITAL } \\
\text { credit sesame }\end{array}$ & $\begin{array}{l}\text { Payments Bac } \\
\text { BlueS } \\
\text { stripe } \\
\text { Klarno } \\
\text { al } \\
\text { credorax }\end{array}$ & 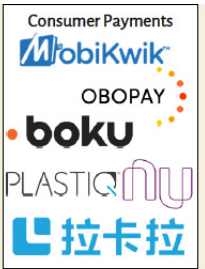 & 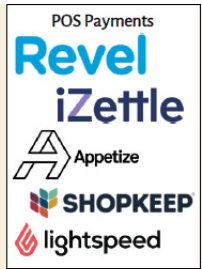 \\
\hline \multicolumn{2}{|c|}{ 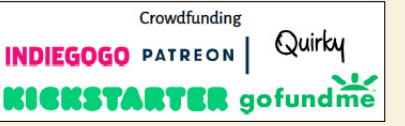 } & \multirow{2}{*}{\multicolumn{2}{|c|}{$\begin{array}{c}\text { FINANCIAL } \\
\text { TECHNOLOGY } \\
\text { Vj/ } / \text { VENTURE } \\
\text { sCANNER } \\
\text { Venture Scanner's emerging technology } \\
\begin{array}{c}\text { research services poweryour corporate } \\
\text { innovation and startup scouting }\end{array}\end{array}$}} & \multicolumn{2}{|c|}{$\begin{array}{l}\text { Atom Digital Banking } \\
\text { TANDEM } \\
\text { TN26 Chime }\end{array}$} \\
\hline Paloneer w Wor & mit currer & & & $\begin{array}{l}\text { I Credit Benchm } \\
\text { AlphaSens }\end{array}$ & 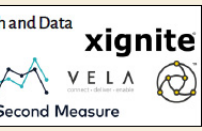 \\
\hline 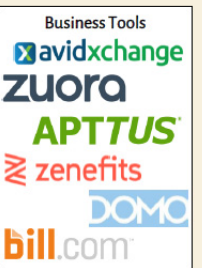 & 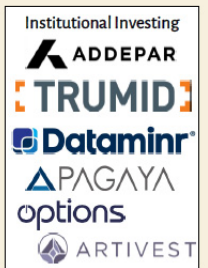 & $\begin{array}{c}\text { m } \\
\text { Bette } \\
\text { Weal }\end{array}$ & $\begin{array}{c}\text { Banking Infrastructure } \\
\text { S syMPHONY } \\
\text { kyriba } \\
\text { Ebury } \\
\text { ncino. }\end{array}$ & $\begin{array}{l}\text { Equity Financing } \\
\text { \& SEEDS } \\
\text { SOurCrowd } \\
\text { SECFI } \\
\text { CircleUp } \\
\text { carta }\end{array}$ & 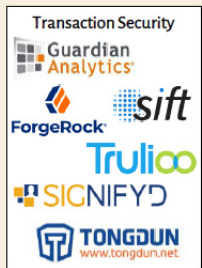 \\
\hline
\end{tabular}

Source: https://www.venturescanner.com/wp-content/uploads/financial-technology-map.pdf.

Fig. 1. FinTech sector map.

Table 1. The distribution of startups over subcategories of the FinTech sector.

\begin{tabular}{lcccc}
\hline Name of subcategory & $\begin{array}{c}\text { Number } \\
\text { of countries }\end{array}$ & $\begin{array}{c}\text { Number } \\
\text { of companies }\end{array}$ & $\begin{array}{c}\text { Number } \\
\text { of investors }\end{array}$ & $\begin{array}{c}\text { Amount } \\
\text { raised }\end{array}$ \\
\hline Banking infrastructure & 32 & 198 & 577 & $\$ 5.81 \mathrm{~B}$ \\
Business lending & 30 & 266 & 1021 & $\$ 26.73 \mathrm{~B}$ \\
Consumer and commercial & 21 & 102 & 393 & $\$ 9.43 \mathrm{~B}$ \\
$\quad$ banking & 37 & 382 & 1308 & $\$ 48.46 \mathrm{~B}$ \\
Consumer lending & 42 & 216 & 732 & $\$ 37.77 \mathrm{~B}$ \\
Consumer payments & 24 & 90 & 232 & $\$ 913.75 \mathrm{M}$ \\
Crowdfunding & 25 & 153 & 357 & $\$ 2.45 \mathrm{~B}$ \\
Equity financing & 13 & 97 & 251 & $\$ 1.86 \mathrm{~B}$ \\
Financial research and data & 16 & 122 & 514 & $\$ 4.38 \mathrm{~B}$ \\
Financial transaction security & 21 & 228 & 513 & $\$ 3.85 \mathrm{~B}$ \\
Institutional investing & 18 & 90 & 378 & $\$ 3.68 \mathrm{~B}$ \\
International money transfer & 41 & 261 & 780 & $\$ 35.9 \mathrm{~B}$ \\
Payments backend and & & & & \\
$\quad$ infrastructure & 34 & 288 & 813 & $\$ 8.14 \mathrm{~B}$ \\
Personal finance & 38 & 206 & 661 & $\$ 11.31 \mathrm{~B}$ \\
Point of sale payments & 29 & 201 & 596 & $\$ 5.3 \mathrm{~B}$ \\
Retail investing & 32 & 331 & 993 & $\$ 15.98 \mathrm{~B}$ \\
Small and medium business tools & & & &
\end{tabular}




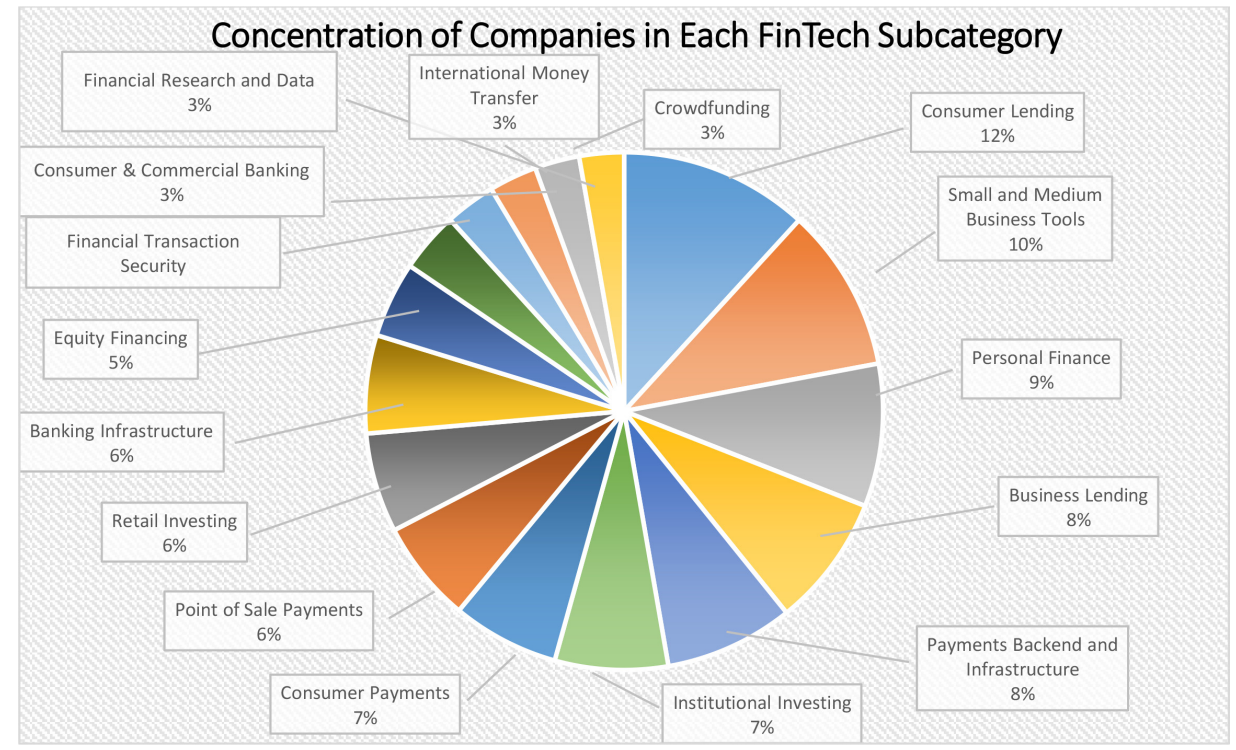

Fig. 2. The concentration of companies in FinTech subcategories.

which offers a wide range of innovative products in point of sales, payments, funding, and partner applications. ${ }^{\mathrm{b}}$

Figure 2 shows the concentration of companies in each FinTech subcategory in the Venture Scanner database as of January 2020. The biggest subcategory is in the Consumer Lending space, making up $12 \%$ of the companies in the Venture Scanner database. This includes some well-known FinTech companies such as SoFi and CommonBond. The former is a P2P lending platform which matches investors who are looking to earn higher returns by building a portfolio of microloans with individuals who may not be able to access credit through traditional sources. And the latter is a FinTech lender that helps individuals to refinance their student loans, with all of their transactions completed through their web-based platform and decisions are made very rapidly, which is more efficient than other private student lenders. Furthermore, CommonBond is able to keep interest rates low and competitive by securitizing student loans that are funded through their platform which also helps to free up capital to make new loans. The Business Lending subcategory is quite well represented as well, making up $8 \%$ of the companies in the Venture Scanner database. The Atlanta-based company, Kabbage, which helps to provide funding to small and medium-sized businesses is among the famous names within this subcategory.

Personal Finance FinTech companies make up 9\% of the Venture Scanner database, with Credit Karma as a representative example. The San Francisco-based company was founded in 2007 and launched the web-based version of its service in 2008. The service could be accessed via the mobile app since 2012. Credit Karma's

biZettle was acquired by PayPal in September 2018. 
Total Amount of Capital Raised ( in millions of USD)

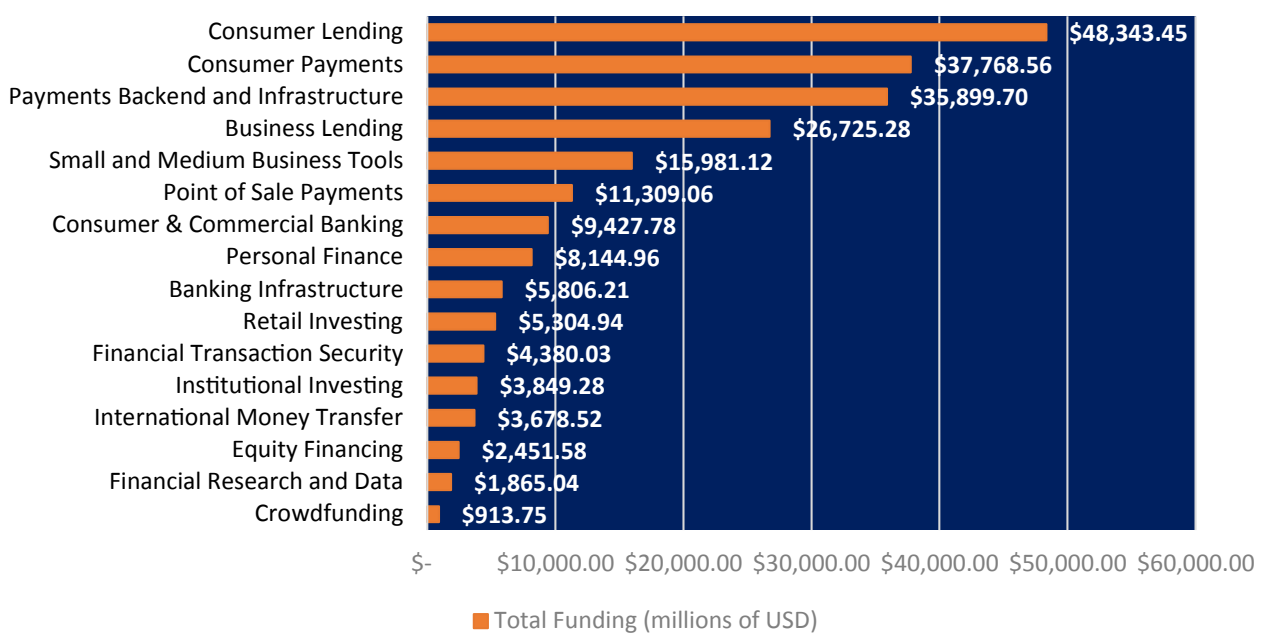

Fig. 3. The distribution of total capital raised over different FinTech Subcategories.

services, including accessing credit scores and credit reports, tax preparation, and information on various financial products, are totally free to its users. ${ }^{c}$ The company makes money entirely from targeted advertisements as well as referral fees for recommending partner lenders to their users. The smallest subcategory in the Venture Scanner database is crowdfunding, which makes up just under $3 \%$ of the companies, includes companies such as Kickstarter and Indiegogo. Both of these crowdfunding platforms, which have raised a combined $\$ 66.5$ million in venture capital, are featured prominently in the case study "Crowdfunding: A Tale of Two Campaigns" (Zacharakis \& Muller 2016). These platforms allow startups to raise funds in small amounts from many individuals, who in return receive rewards and/or sample products.

Figure 3 displays the total amounts of capital (in millions of dollars) raised by companies in each of the FinTech subcategories over the entire Venture Scanner sample up to January 2020. Consumer Lending startups have raised the largest amount of funding, which is more than $\$ 48$ billion. This is followed by Consumer Payments and Payments Backend and Infrastructure with almost $\$ 38$ billion and $\$ 36$ billion funded, respectively. Business Lending comes in fourth with over $\$ 26$ billion of capital raised. After that, the amounts drop off significantly. Investing (retail and institutional combined) has raised over $\$ 9$ billion. On the retail investing side, this includes companies such as the robo-advisors Wealthfront and Betterment as well as the micro-investing platform Acorns. On the .institutional side, this includes companies such as San Diego-based Artivest which operates as a platform

c In February 2020, Intuit made an offer to acquire Credit Karma for over $\$ 7$ billion. 


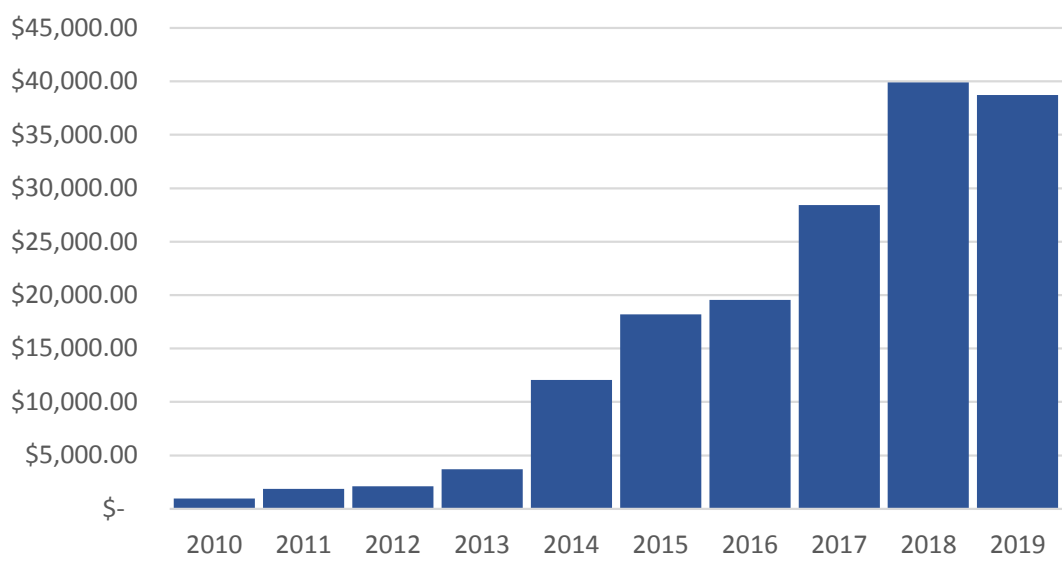

Fig. 4. The distribution of Annual FinTech Funding over 2010-2019.

for alternative investments. Crowdfunding has raised the smallest amount, with less than $\$ 1$ billion in total funding.

Figure 4 shows the trends in aggregate FinTech Company funding over time. In each year from 1999 to 2009, the annual FinTech funding was under $\$ 1$ billion, so these years have been omitted to save space and preserve scale. For example, funding was only $\$ 66.1$ million in 1999 . By the peak of the tech bubble in 2000 , funding was $\$ 676$ million but dropped off to $\$ 5.54$ million in 2003 . Funding returned to its 2000 level in 2008 when it was about $\$ 678$ million. In 2010, funding for FinTech companies exceeded $\$ 1$ billion for the first time, coming in at just over $\$ 1.1$ billion. After 2013 , the funding for FinTech companies accelerated dramatically. From Fig. 4, it can be seen that the annual funding for FinTech companies took off at almost an exponential rate since 2010 despite a small dip in 2019, which may suggest a slight cooling off of total investment in FinTech startups. In 2011, the total FinTech funding was over $\$ 1.8$ billion. It increased to over $\$ 2.1$ billion in 2012 and increased to over $\$ 3.7$ billion in 2013. In 2014, it jumped to almost $\$ 12$ billion, more than triple the previous year. In 2015, the amount of FinTech funding was over $\$ 18$ billion, in 2016 it was over $\$ 19.5$ billion, and in 2017 increased another $45 \%$ to almost $\$ 28.5$ billion. By 2018, FinTech funding was bumping up against $\$ 40$ billion.

Similar to other types of startups, FinTech companies raise money in stages. Typically, this begins with "Seed Funding" which may often come from an Angel Investor, family, and/or friends; some Seed Funding has also been known to come from founders' credit cards (Fabozzi 2016). In fact, Google's first 2 years of operations were financed with credit cards. ${ }^{\mathrm{d}}$ Seed Funding can also come from accelerators and incubators. Seed Funding is used to help the company to literally start up. Once the companies are established and exhibit some potential for success (not necessarily

${ }^{\mathrm{d}}$ For more details, please see Fabozzi (2016, page 100) and the references therein. 


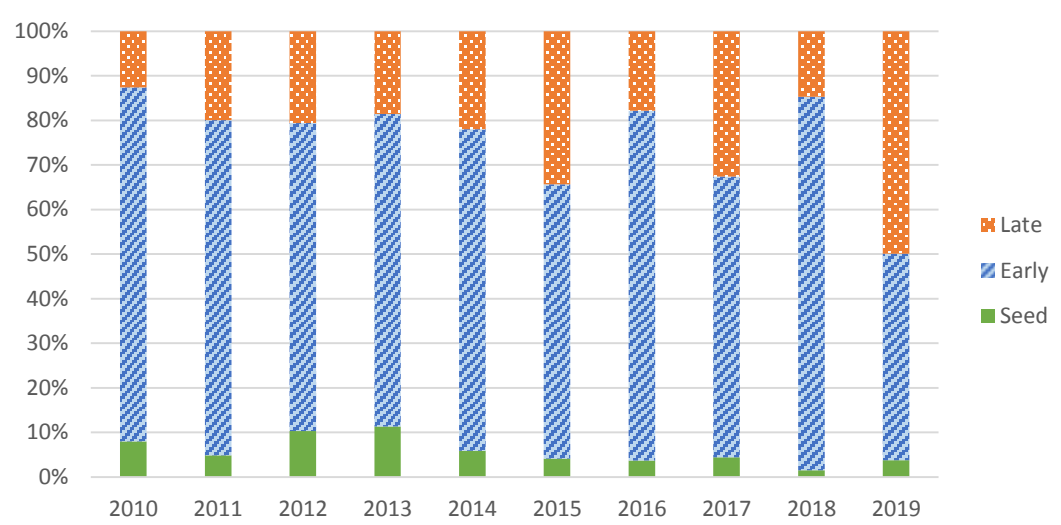

Fig. 5. The composition of fund raised by FinTech firms over 2020-2019.

profitable though), they typically will raise money from VCs. "Early Stage" VC investments include Series A, Series B, Series C equity investments, and sometimes venture debt. The proceeds of Early-Stage funding are typically used to build out and scale the company. There is extensive literature on VC investment in young firms, with evidence suggesting that VC investments are not only associated with an increase in patenting (Kortum \& Lerner 2000) but also economic growth (Samila \& Sorenson 2011). Independent venture capitalist (IVC) funds are not the only source of capital for innovation activities by firms as we have also seen an influx of investments from corporate venture capital (CVC), such as Comcast Ventures, Google Ventures, Intel Capital, Johnson \& Johnson Innovation, and Microsoft Ventures (Chemmanur et al. 2014). ${ }^{\mathrm{e}}$

As the company matures and its need for funding continues, it will receive "Late Stage" funding. Late-Stage funding may come from VCs (both IVCs and CVCs) as well as private equity (PE) firms.

Figure 5 shows the composition of fundraising by FinTech firms in each year from 2000 to 2019 using data from the Venture Scanner database. We break the total amount of funding raised by FinTech companies into the Seed (in solid green), Early (in striped blue), and Late (in orange with dots) stages. Given that FinTech is still a relatively young industry, it is not surprising to see that the majority of funding each year through 2018 has come in the form of Early Stage. The biggest year for Seed Funding was in 2013, as discussed earlier, when FinTech investment really started to take off. Interestingly, there was slightly more Late-Stage funding than Early-Stage funding in 2019, suggesting that the market may not necessarily be cooling off significantly, but maybe that the industry is maturing. Therefore, FinTech companies that have already been around for some years would be looking to raise more capital after having shown evidence of strong performance.

eFor a more comprehensive list, please refer to https://www.cbinsights.com/research/corporate-venturecapital-active-2014/. 


\section{T. J. Chemmanur et al.}

\section{Innovation Activities by FinTech Firms}

It is becoming difficult to quantify the amount of innovation that is occurring in the FinTech space. Standard practice in the finance and economics literature is to use patent filings and patent citations as proxies for the amount and impact of innovation, respectively. ${ }^{\mathrm{f}}$ However, Bessen \& Maskin (2009) developed a model in which patents may stifle innovation and follow-up studies have shown that innovation in high-tech software-dependent industries is not well represented by their patenting activities. $^{\mathrm{g}}$ This may be true for FinTech companies as well. Based on our preliminary analysis, FinTech firms, especially startups, do not have a major presence in the USPTO database, which seems to support the model of Bessen \& Maskin (2009). Nevertheless, it is still important to analyze the patenting activities of FinTech firms given that patents are likely to be one of the important indicators for their innovative activities and technologies.

We analyzed the innovation (patenting) activities of FinTech firms by analyzing a sample of 1309 U.S.-based FinTech firms over the period of 1983-2018 obtained from the Venture Scanner database. ${ }^{\text {h }}$ This sample includes firms from various categories such as blockchain, consumer lending, and insurance tech among others. Out of these 1309 firms, 21 (equivalent to $1.6 \%$ of the sample) firms eventually had an IPO and $230(17.6 \%)$ firms were eventually acquired. In Table 2, we present the distribution of FinTech firms into various categories.

Figure 6 displays the distribution of the founding years of FinTech firms. More than $75 \%$ of the firms in our sample were founded after 2009. This evidence suggests that there was substantial growth in the arrival of new entrants in the FinTech space after the financial crisis.

We then match our sample of FinTech firms from Venture Scanner with the patent dataset obtained from the USPTO website, using a fuzzy name matching algorithm following Bernstein et al. (2016). We study the trends of patent counts as well as citations received by these patents filed by FinTech firms over the period of 1983-2015. We restrict our analysis to the year 2015 to account for the lag between patent application and eventual grants, which is known as the truncation bias. We find that 191 FinTech firms (14.6\% of 1309 firms in our sample) have at least one patent. Further, all of these patents were filed after 1990. As shown in Fig. 7, we find an upward trend in patenting by FinTech firms over the years with a sudden jump in patenting after 2010 .

In addition to patent counts, we also analyze the class-adjusted (i.e. three-digit patent technology class adjusted) citations received by these patents. We scale the

\footnotetext{
f The literature is extensive but some early examples include Schmookler (1954), Schmookler \& Brownlee (1962), Mansfield (1986), Jaffe (1986), Scotchmer (1991); and more recently, Tian \& Wang (2014) with respect to corporate innovation and VC-backed IPO's, Lerner et al. (2011) for private equity investment and LBO's, Seru (2014) for corporate R\&D investment, and Bena \& Li (2014) for M\&A deals.

g Please refer to Alice v. CLS Bank. A recent paper by Srinivasan (2018) actually shows that after this Supreme Court ruling, that R\&D spending actually increased in response to decreased patent protection. $\mathrm{h}$ Please refer to Sec. 3 for a detailed description of the Venture Scanner database.
} 
Table 2. The distribution of Fintech firms in different categories.

\begin{tabular}{|c|c|c|c|}
\hline Category & Frequency & Percent & Cumulative \\
\hline Auto insurance & 13 & 0.99 & 0.99 \\
\hline Banking infrastructure & 42 & 3.21 & 4.2 \\
\hline Blockchain innovations & 89 & 6.8 & 11 \\
\hline Business lending & 63 & 4.81 & 15.81 \\
\hline Consumer insurance management platforms & 6 & 0.46 & 16.27 \\
\hline Consumer lending & 104 & 7.94 & 24.22 \\
\hline Consumer payments & 21 & 1.6 & 25.82 \\
\hline Consumer and commercial banking & 18 & 1.38 & 27.2 \\
\hline Crowdfunding & 34 & 2.6 & 29.79 \\
\hline Digital asset big data & 3 & 0.23 & 30.02 \\
\hline Digital asset business services & 5 & 0.38 & 30.4 \\
\hline Digital asset exchanges & 21 & 1.6 & 32.01 \\
\hline Digital asset financial services & 22 & 1.68 & 33.69 \\
\hline Digital asset gambling & 1 & 0.08 & 33.77 \\
\hline Digital asset infrastructure & 7 & 0.53 & 34.3 \\
\hline Digital asset mining & 1 & 0.08 & 34.38 \\
\hline Digital asset news and data services & 1 & 0.08 & 34.45 \\
\hline Digital asset payments & 12 & 0.92 & 35.37 \\
\hline Digital asset trust and verification services & 5 & 0.38 & 35.75 \\
\hline Digital asset wallets & 11 & 0.84 & 36.59 \\
\hline Employee benefits platforms & 12 & 0.92 & 37.51 \\
\hline Enterprise/commercial insurance & 19 & 1.45 & 38.96 \\
\hline Equity financing & 36 & 2.75 & 41.71 \\
\hline Financial research and data & 29 & 2.22 & 43.93 \\
\hline Financial transaction security & 50 & 3.82 & 47.75 \\
\hline Health/travel insurance & 49 & 3.74 & 51.49 \\
\hline Institutional investing & 95 & 7.26 & 58.75 \\
\hline Insurance comparison/marketplace & 29 & 2.22 & 60.96 \\
\hline Insurance data/intelligence & 32 & 2.44 & 63.41 \\
\hline Insurance education/resources & 1 & 0.08 & 63.48 \\
\hline Insurance infrastructure/backend & 63 & 4.81 & 68.3 \\
\hline Insurance user acquisition & 14 & 1.07 & 69.37 \\
\hline International money transfer & 15 & 1.15 & 70.51 \\
\hline Life, home, property and casualty insurance & 19 & 1.45 & 71.96 \\
\hline $\mathrm{P} 2 \mathrm{P}$ insurance & 2 & 0.15 & 72.12 \\
\hline Payments backend and infrastructure & 65 & 4.97 & 77.08 \\
\hline Personal finance & 88 & 6.72 & 83.8 \\
\hline Point of sale payments & 37 & 2.83 & 86.63 \\
\hline Product insurance & 5 & 0.38 & 87.01 \\
\hline Retail investing & 49 & 3.74 & 90.76 \\
\hline Small and medium business tools & 121 & 9.24 & 100 \\
\hline Total & 1309 & 100 & \\
\hline
\end{tabular}

number of citations received on all patents filed by a given firm in an application year by the citations received by all patents filed in the same three-digit technology class and in the same application year. As shown in Fig. 8, we observe a jump in the classadjusted citations after 2010, suggesting that the quality of patents filed by FinTech firms improved in recent years. 


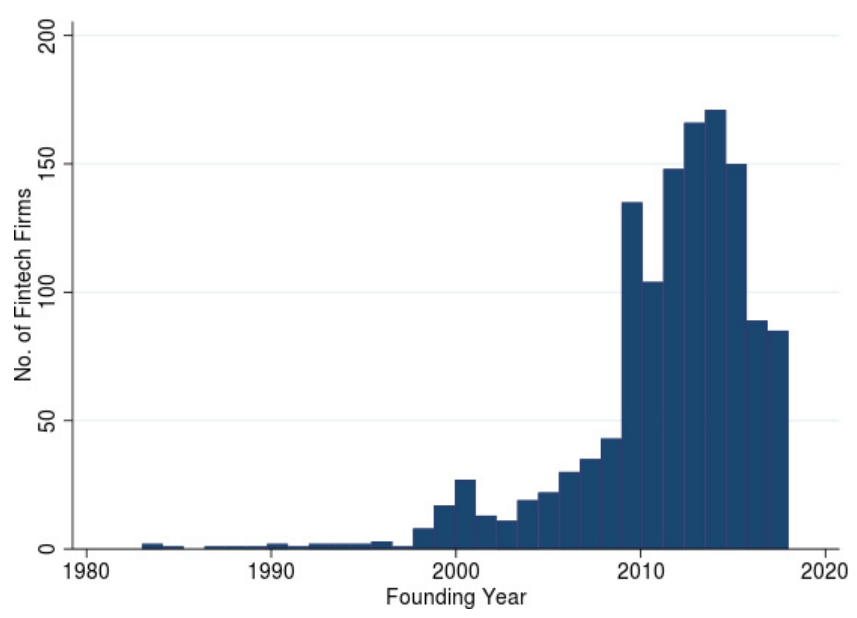

Fig. 6. The distribution of founding years of FinTech firms.

Another interesting question in the FinTech research area is to compare and contrast the innovation activities of incumbents (traditional intermediaries) versus new entrants (FinTech startups). Chen et al. (2019) show that most of the valuable patents in the financial sector have been filed in the IoT, robo-advising, and blockchain sectors. They also find that majority of patents are filed by firms outside the financial sectors, i.e. mostly technology firms. In Sec.7, we will discuss two options available to new entrants ("build versus buy"): developing new technologies or innovations from scratch versus acquiring innovation and how these options affect the innovation activities of firms.

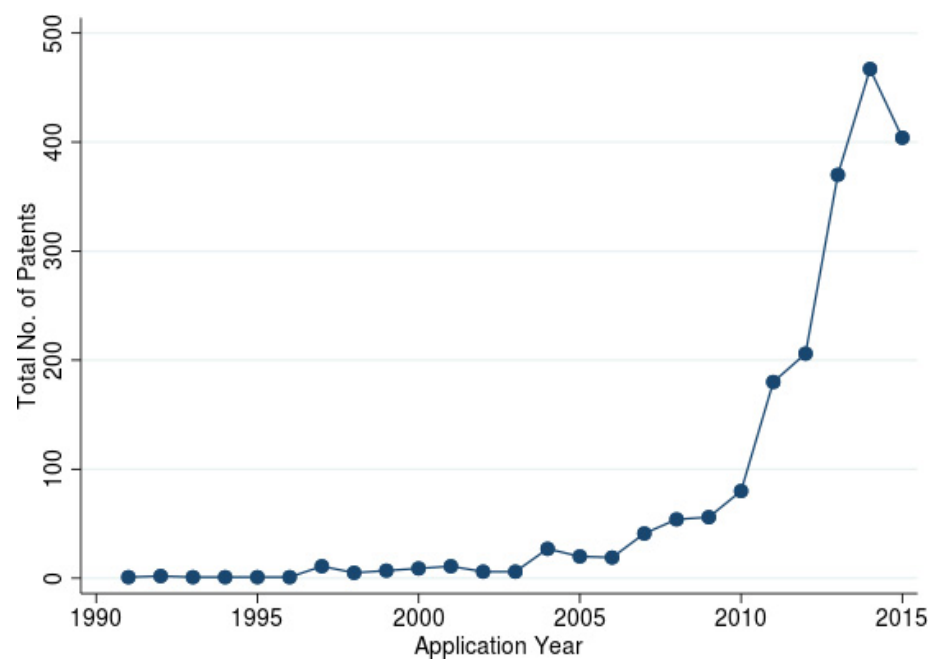

Fig. 7. The number of patent applications filed by FinTech firms over 1990-2015. 


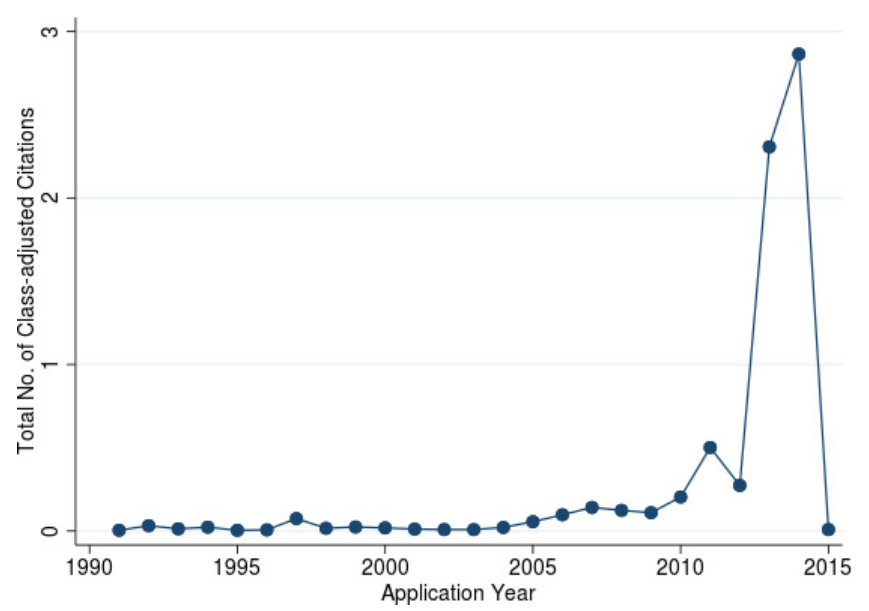

Fig. 8. The total class-adjusted citations received by patents filed by FinTech Firms over 1990-2015.

\section{Sources of Value-Creation by FinTech Firms: Improving the Consumer Finance Experience and Banking the Unbanked}

As shown in Sec. 3, investment in FinTech took-off after 2013. In this post-crisis era, there was a loss of confidence and trust in traditional financial institutions among consumers; this combined with the advancing pace of technology was a major impetus to "Big Tech" (large technology companies like Google, Facebook, etc.) and startups in creating more user-friendly products using mobile and wireless technology in particular. During this time, mobile app downloads grew globally from 100.4 billion in 2014 to 195.9 billion in 2018 and to a projected 215.7 billion downloads in 2019. This pattern can be seen in Fig. 9, which shows the breakdown in the number of mobile app downloads by geographic region based on the data sourced from Statista.

Through the development of mobile apps and the application of big data analytics, FinTech companies have been able to use publicly available data and create easy-to-use mobile interfaces to provide free financial information to consumers (e.g. Credit Karma). FinTech companies have introduced an easier and more convenient way of banking as borrowers and depositors do not have to physically visit a branch but rather can perform many routine tasks with the push of a button on an app on their mobile devices. For example, mobile deposit was first introduced by the United Services Automobile Association (USAA) in 2009 and fully online mortgages are available now through RocketMortgage, which was launched by Quicken Loan in 2016.

In fact, mobile banking has grown significantly across all demographics in the first half of the last decade. This is shown in Fig. 10 which displays the distribution of mobile banking users as a percentage of their respective demographics from 
Mobile App Downloads (in billions)

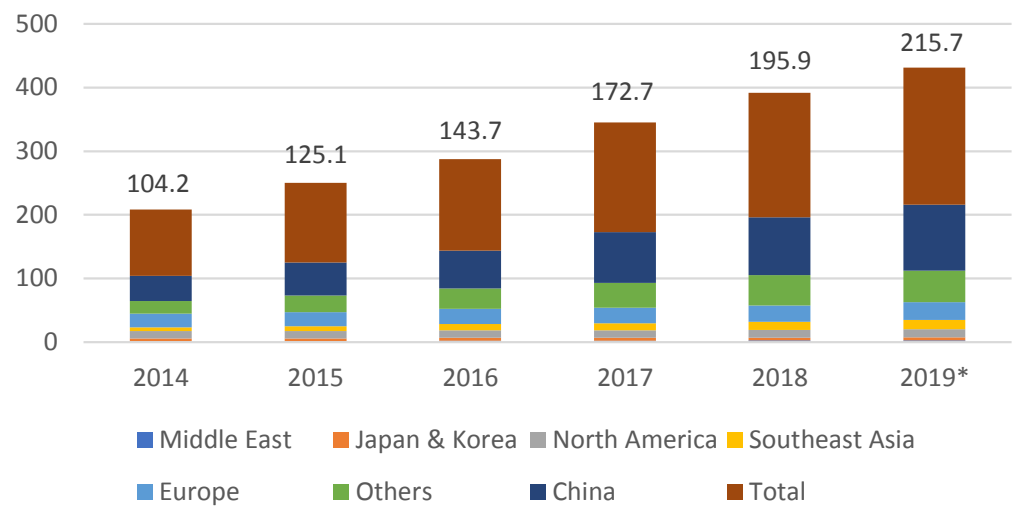

Fig. 9. The distribution of mobile app downloads by geographic region over 2014-2019.

Distribution of the percentage of Mobile Banking Users

by age group

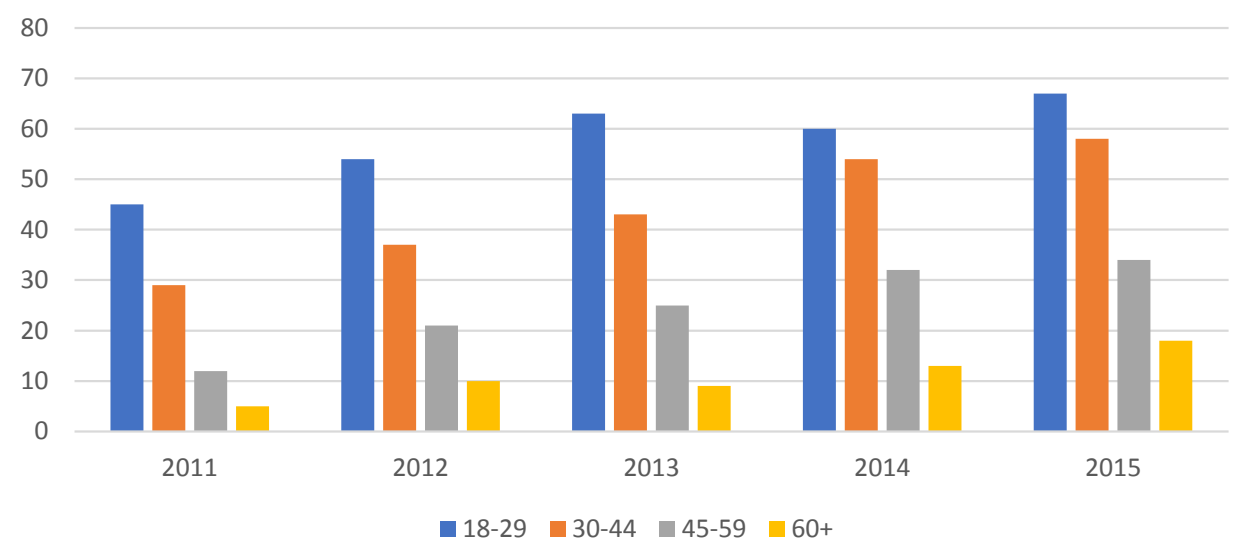

Fig. 10. The distribution of mobile banking users by age group over 2011-2015.

2011 to 2015, based on the data sourced from Statista. The Millennial demographic (aged 18-29), which is considered as "digitally native" increased from $45 \%$ in 2011 to $67 \%$ in 2015 . Even retirees (aged 60 and above), a demographic which is not known for being major users of new technologies, increased from $5 \%$ in 2011 to $18 \%$ in 2015.

By leveraging user-friendly interfaces and harnessing insights from big data analytics, FinTech companies have been able to excel at providing a much more engaging experience for their customers. In recent years, there have been an increase in CX and User Experience (UX) Designer positions at FinTech firms so that the 
products are designed with the users' needs in mind. ${ }^{i}$ Many financial apps, which are developed by FinTech companies either in standalone apps or licensed to the big financial incumbents, have location monitoring and push notifications. This allows for a more interactive experience for customers. For example, a payment app is able to recognize that a customer just walked past her favorite coffee shop which is running a " $50 \%$ off" deal on iced specialty beverages. The app will immediately send her a push notification thereby driving her into the store, generating transactions for the payment app. Furthermore, the UX Engineers at the FinTech companies can analyze the data and figure out how often these push notifications are likely to result in a sale. Another example, from the retail investment subcategory of FinTech, might be the use of event alerts on one's mobile device to prompt trading. An investing app may send users a push notification when a company whose stock they own, or is on their "watch list," is announcing earnings. They might even include a link to the company's research on whether they expect earnings to beat or miss analyst expectations. The investor can then make an informed decision about whether they want to buy, sell, or just hold onto their position with the earnings announcement coming up. As with the payments technology example, this results in a higher likelihood of transaction and the aggregation of user statistics can be used to quantify and even predict the effectiveness of this technology.

It is true that many of the latest technology breakthroughs, especially when it comes to mobile apps, have been made by FinTech startups rather than the financial incumbents. The former, despite being newcomers to the market without a wellestablished reputation yet, are viewed generally as more customer friendly and socially conscious. FinTech companies around the world pride themselves on improving financial literacy and financial inclusion. Many of the FinTech products that are available today have an educational component that is seamlessly integrated. Customers thus can not only utilize the technology to bank or invest, but also acquire some knowledge of budgeting and wealth planning.

The incumbents often tend to be a stodgy group which historically has put share price and profits over customer satisfaction. Since the financial crisis, they have even been labeled as "greedy fat cats" that have preyed on the lack of financial literacy in the market and charge exorbitant fees in their quest to get rich. ${ }^{j}$ Some have aimed to change that image and simultaneously have licensed technology from FinTech companies or have developed their own technology in-house.

In traditional finance theory, the objective function of a typical corporate optimization problem is to maximize shareholder value, an idea that can be traced back

\footnotetext{
${ }^{\mathrm{i}}$ Although often used interchangeably, experts contend that CX is more of a macro or holistic approach that develops a brand image with which the customer identifies; UX, on the other hand, is more of a micro perspective, at the transaction level. These can usually be more easily quantified with metrics such as "clicks," "hit rates," or how often a prompt or recommendation results in a sale.

jPlease refer to "Stop the fat-cat bonuses! George Soros turns on the bankers" by David Randall and Margareta Pagano, October 25, 2009, The Independent: https://www.independent.co.uk/news/business/ news/stop-the-fat-cat-bonuses-george-soros-turns-on-the-bankers-1809138.html.
} 


\section{T. J. Chemmanur et al.}

to Milton Friedman in the 1970s. This suggests that subject to certain constraints, the business is considered to be successful as long as shareholder value increases. No other stakeholders (such as employees, suppliers, and customers) matter in the traditional decision process. Although the CEOs sometimes may argue that customers are their most important stakeholders, their actions may not support their claims. ${ }^{\mathrm{k}}$ In contrast to the above strict shareholder value maximization approach, some FinTech starts seem to be targeted at the needs of specific consumers, as revealed by the innovative financial services they have offered recently.

Thus, developing products that the customers actually like to use (i.e. satisfying the needs of specific groups of consumers) seems to be at the core of FinTech innovation, at least in the case of some FinTech start-ups and the services they offer. According to the "Voice of the Consumer Survey," a report released by Capgemini and LinkedIn in 2017, 44.8\% of customers use at least one FinTech provider (in addition to traditional firms) for investment management services and $29.4 \%$ of customers surveyed said they use at least one FinTech provider (in addition to traditional banks) to do their banking.

When it comes to financial services providers, such as banks and asset managers, trust by consumers is clearly paramount. The survey quoted in the previous paragraph asked customers to rate on a scale of 1 to 7 "What level of trust do you have in the following entities: traditional financial services companies, nontraditional 'Big Tech' firms (e.g. Amazon, Google, Apple, etc.), and nontraditional FinTech firms?" where 1 represents total distrust and 7 represents a very high level of trust. The question was asked of people unconditionally and then conditional upon having had a positive experience. We observe some interesting results from the survey: the unconditional response was that $36.6 \%$ of customers trust traditional financial institutions and $23.6 \%$ of customers trust FinTech and Big Tech firms. This suggests that there may not be a high level of trust for FinTech and Big Tech firms as customers may not have used their services or happened to have a negative experience from limited experience. However, after a positive experience, the level of trust for customers of both traditional institutions and FinTech and Big Tech firms jump above $50 \%$. However, more customers trust in Big Tech and FinTech firms: $56.3 \%$ of customers responded that they trust FinTech and Big Tech firms, while $52.9 \%$ of customers responded that they trust in traditional financial services firms. This seems to confirm the hypothesis that trust in a challenger or new entrant into a space

\footnotetext{
${ }^{\mathrm{k}}$ A big bank that got in trouble for violating the trust of its customers is Wells Fargo. In 2013, the Los Angeles Times reported in an expose that Wells Fargo had placed unrealistic sales goals and quotas on their bank managers and sales force to open up new accounts. It was further revealed that over 2 million false accounts (or as many as 3.5 million as indicated by some sources) were created to this end. After an investigation, in 2016, the Consumer Finance Protection Bureau (CFPB) levied a ruling that Wells Fargo was in violation of the Consumer Financial Protection Act (part of Dodd-Frank) which resulted in a fine of $\$ 185$ million. Over 5000 employees were fired and the then-CEO, John Stumpf, took responsibility and apologized for failing to fulfill the company's responsibilities to their customers. He stepped down in October 2016 and later it was announced that Stumpf is banned from the banking industry for life and was personally fined $\$ 17.5$ million.
} 
such as investments or banking takes time to build and is heavily conditional on first impressions. Note that although the survey was conducted in 2016, the results are still likely to apply to the current market; also, we may expect that these results have changed probably more in favor of trusting FinTech as FinTech has moved more mainstream in recent years.

Trust and positive CX also vary along different dimensions, and this is another question investigated by the "Voice of the Customer Survey." It seems that an overwhelming majority of customers feel more comfortable with traditional financial service firms when it comes to security and fraud protection (i.e. $74.3 \%$ for traditional financial service firms versus $5.4 \%$ for the FinTech providers). When it comes to the quality of service, traditional financial service firms provided a better experience than FinTech (i.e. $47.3 \%$ of customers vote for traditional financial service firms versus $21.6 \%$ for FinTech companies). However, in the following categories, FinTech companies dominated the traditional financial service firms: value, timely and efficient service, transparency (which again ties back to trust), convenience, and UX. The last category above was rather overwhelming with $67.6 \%$ of customers having a better UX experience with FinTechs versus just 9.5\% having a better UX experience with traditional financial services firms.

In sum, in developed countries and markets, the trend has been for FinTech companies to create value by winning and retaining customers through more userfriendly technology and superior UX design. The combination of decreased trust in incumbent financial institutions in the wake of the Financial Crisis combined with the rise in usage of mobile technologies represented an ideal entry point for tech firms offering financial services by way of smartphone apps and other technologies. Interestingly, though, recent surveys indicate that customers are still more likely to trust the financial service incumbents with issues in cybersecurity and fraud. However, it will be interesting to see how much progress will be made by FinTech companies that are working on emerging technology in the above area in the next few years.

In closing, it would also be useful to consider the development of FinTech and the sources of value creation by FinTech start-up firms in developing countries and other emerging markets where traditional banking has left many types of consumers behind. As Canuto (2020) points out, FinTech firms have the power to drastically improve the financial landscape for underserved populations in Africa, Latin America, and the Caribbean. But for FinTech's potential in these countries to be fully realized, national governments will need to adapt regulatory environments to keep up with the times. The good news is that some policymakers are starting to pick up the pace; the bad news is that there is much work left to be done.

A recent IMF working paper (Berkmen et al. 2019) describes numerous deficiencies in developing countries (especially in Latin America) when it comes to financial access, the depth of financial tools available to customers, and the efficiency of financial markets. Despite some variation across countries, low credit-to-GDP ratios, high service fees, heavy reliance on nontraditional finance sources, and large 


\section{T. J. Chemmanur et al.}

unbanked populations are common in these markets. In each of these areas, there is a place for FinTech to make markets work better for average people. To give one example (pointed out by Canuto 2020), mobile operators can now supply bankingrelated tools to clients directly on their phones, while e-commerce platforms offer numerous other mobile payment services. In remote areas, mobile technology and bank-appointed agents on the ground make reaching unbanked customers easier than ever before.

The above technologies have been deployed widely in Asia and Africa for more than a decade. For example, banking services initiated by M-Pesa in Kenya in 2007 have already reached over 30 million users in 10 countries. The broad use of mobile payment services has also grown very rapidly in China (perhaps faster than in the United States). However, Latin America lags behind (as pointed out by Canuto 2020, Berkmen et al. 2019). Using mobile banking to send money across borders could help cut the cost of remittances, which correspond to 1.5\% of GDP in Latin America and the Caribbean and up to $15 \%$ of GDP in places like El Salvador, Haiti, Honduras, and Jamaica. Despite the region's high share of global remittances, its use of mobile money to send and receive them is relatively low, with costly traditional banks and money transfer operators still dominating the market. ${ }^{1}$

\section{The Regulatory Environment Facing FinTech Firms}

In this section, we discuss the role that financial regulators have played thus far as FinTech has grown in recent years. Financial regulators and central banks, globally, have to grapple with the challenge of balancing financial stability and innovation. Whereas the latter can lead to growth, it can also introduce instability if not done in a controlled manner. Therefore, this balance is paramount. Here we will look at how regulators in the United States (including the Federal Reserve, Federal Deposit Insurance Company (FDIC), Comptroller of the Currency, and Securities and Exchange Commission (SEC)), the United Kingdom and Europe (including the Financial Conduct Authority (FCA), Bank of England (BoE), European Central Bank, and Bank for International Settlements (BIS)) and Asia have addressed the FinTech regulation over the past few years.

\subsection{Regulation of banking-related activities}

In the United States, the Federal Reserve Board oversees the entire Federal Reserve System and is therefore responsible for regulating member banks. They are also the primary regulators for Bank Holding Companies (BHC). Within the Federal Reserve System, there are 12 regional Federal Reserve Banks. Among the 12 Federal Reserve Banks and the Board, there are numerous FinTech-related initiatives that are ongoing, although none appears to be centrally coordinated. The Board, for example,

\footnotetext{
${ }^{1}$ Traditional banks in the region charge roughly $6 \%$ to send remittance payments, compared to the $3 \%$ paid by mobile remittance users in sub-Saharan Africa (see, again, Canuto 2020).
} 
has economists examining real-time payments and clearing technologies and the potential use of blockchain technology. Additionally, in December 2019, the Federal Reserve Board launched a program for which a newly formed Innovation Office holds "Office Hours" in two locations (Philadelphia and Atlanta) to discuss technological innovation in banking and how banks and FinTech companies are partnering together. ${ }^{\mathrm{m}}$

Four of the Federal Reserve Banks have dedicated groups that are working on the FinTech area. The Federal Reserve Bank of San Francisco (FRBSF) has a group called "Navigate" that is dedicated to FinTech Innovation. " The Navigate Team interacts with Bay Area FinTech companies and banks so that technological innovation can be pursued in financial services but with an understanding of the very gray area that currently exists. In fact, these are the most challenging aspects of FinTech regulation. First of all, there is not yet a well-established framework for regulating FinTech or the entrance of tech companies into financial services. The decades old regulations that apply to BHCs do not apply to FinTech, which in some ways may benefit the FinTech and tech companies. For example, FinTech companies are not subject to capital adequacy requirements or federal stress testing. However, FinTech companies also do not have the rights and privileges that BHCs and Fedmember banks have. This provides a barrier to entry and a sense of security to the incumbent banks. Second, and herein lies the challenge for the financial regulators including the Fed and the Navigate group at the FRBSF: regulation and innovation are something of a balancing act.

The Federal Reserve Bank of New York established the FinTech Advisory Group in 2019. ${ }^{\circ}$ The Advisory Group meets twice a year and is composed of senior executives from the tech industry, financial incumbents, FinTech companies, and consulting firms. The Advisory Group and senior policymakers from the New York Fed, including the Bank President, exchange ideas regarding the current trends in FinTech and how to approach them from a regulatory and strategic perspective. The Federal Reserve Bank of Atlanta is home to the Center for Financial Innovation and Stability under the leadership of its Director, Larry Wall (see also Wall 2018). ${ }^{\mathrm{p}}$ This Center is concerned with regulatory issues concerning FinTech firms, sponsors an annual conference on financial markets related to the above issues (namely, the Financial Markets Conference), and computes market-implied probabilities for short-term interest rates. ${ }^{\mathrm{q}}$

\footnotetext{
${ }^{m}$ https://www.federalreserve.gov/aboutthefed/innovation-office-hours-series.htm.

n Please refer to the following link for more details: https://www.frbsf.org/banking/fintech/about/? utm_source=frbsf-fintech-home\%20about\&utm_medium=frbsf\&utm_campaign=fintech.

o https://www.newyorkfed.org/aboutthefed/ag_fintech.html.

phttps://www.frbatlanta.org/cenfis.aspx.

qThe methodology is based on "simplex regression" with details that can be found in Fisher (2016). For more information, please see https://www.frbatlanta.org/-/media/documents/cenfis/market-probabilitytracker/market-probability-tracker_simplex-regression.pdf. Also see https://www.frbatlanta.org/-/ media/documents/cenfis/market-probability-tracker/market-probability-tracker_estimation-specifics. pdf.
} 


\section{T. J. Chemmanur et al.}

There is also the Mobile Payment Industry Workgroup at the Federal Reserve Bank of Boston. ${ }^{\mathrm{r}}$ This group at the Boston Fed is primarily interested in researching trends in mobile payments, digital currencies, and similar topics. Lastly, the Federal Reserve Bank of Cleveland co-sponsors, with the U.S. Department of the Treasury's Office of Financial Research, an annual conference on financial stability. The entire theme for the 2017 conference was "Financial Stability and Fintech" and at the 2019 conference, there were several sessions dealing with emerging technologies and their relationship to financial stability. ${ }^{\mathrm{s}, \mathrm{t}}$ And in 2018, the Cleveland Fed hosted a conference on P2P financial services. ${ }^{\mathrm{u}}$

In the United States, the FDIC is the primary regulator for state-chartered banks that are nonmembers of the Federal Reserve System. Further, the FDIC oversees and administers the Deposit Insurance Fund (DIF) which is used to compensate depositors who have funds in a participating depository institution that is placed in receivership. Going back several years, to at least 2017, there was a lot of talk about FinTech firms considering to register as an Industrial Loan Company (ILC) that would be subject to the FDIC approval and contribute to its DIF. ${ }^{\mathrm{v}}$ The FinTech company, Square, which has most commonly been associated with payment technologies, has moved into other area of small and medium enterprise (SME) financing, entertained the ILC application in recent years. The P2P lending firm SoFi applied for the ILC charter in 2017 but withdrew their application after a scandal about a toxic work culture emerged. ${ }^{\mathrm{w}}$

More recently, however, there has been a trend toward FinTech companies going the traditional route to get FDIC-insured deposits as a source of funding. In February 2020, the San Francisco-based Varo Money was the first digital banking FinTech company to achieve FDIC regulatory approval. Around the same time, the marketplace lending platform and publicly traded FinTech company Lending Club announced that it is acquiring the FDIC regulated bank, Radius Bank from Boston, for $\$ 185$ million.

Another agency that plays a very important role in the regulation of banks in the United States is the Office of the Comptroller of the Currency (OCC). The OCC is an independent bureau of the U.S. Department of the Treasury and is the primary regulatory agency for all nationally chartered banks. In fact, the OCC grants licenses

\footnotetext{
${ }^{\mathrm{r}}$ https://www.bostonfed.org/publications/mobile-payments-industry-workgroup.aspx.

s https://www.clevelandfed.org/en/newsroom-and-events/events/2017/financial-stability-conference. aspx.

${ }^{\mathrm{t}}$ https://www.clevelandfed.org/newsroom-and-events/events/2019/2019-financial-stability-conference/ agenda.aspx.

u https://www.clevelandfed.org/newsroom-and-events/events/2018/2018-p2p-financial-systems-international-workshop.aspx.

v "Fintech Firms Look to Enter Banking Via Century-Old Tactic," by Lalita Clozel (February 8, 2018), Wall Street Journal; available at https://www.wsj.com/articles/fintech-firms-look-to-enter-banking-viacentury-old-tactic-1518085801.

w "SoFi withdraws bank application in wake of scandal," by Lalita Clozel (October 13, 2017), American Banker; available at https://www.americanbanker.com/news/sofi-withdraws-bank-application-in-wakeof-scandal.
} 
and charters to all national banks, savings associations, and federal branches. Furthermore, the Office of Thrift Supervision (OTS) was merged into the OCC effectively in 2011, giving the OCC oversight of thrifts and savings and loan associations as well. The OCC was one of the first financial regulators in the United States to proactively embrace FinTech innovation. In 2016, the OCC opened up the Office of Innovation under the leadership of Chief Innovation Officer Beth Knickerbocker. ${ }^{\mathrm{x}}$ The group reporting to her includes Innovation Officers in Washington, DC, New York City, and San Francisco. The Office is mandated with ensuring a regulatory framework for banks and FinTechs that is conducive to "responsible innovation" which is defined as "the use of new or improved financial products, services and processes to meet the evolving needs of consumers, businesses, and communities in a manner that is consistent with sound risk management and is aligned with the bank's overall business strategy." $\mathrm{y}$

Much of what the OCC Office of Innovation does is outreach and engagement with FinTech firms, universities, Think Tanks, and most importantly, banks. Their Innovation Officers are trying to better understand how technological innovation is changing (and will change) the state of the banking system and allow innovation to thrive while at the same time not become reckless. In fact, this is precisely the balance that we discussed at the beginning of the section.

Internationally, the BIS has a number of initiatives underway that examine how technological innovation is changing banking activities and regulations globally. This includes a new strategy referred to as "Innovation 2025," which is BIS's medium-term (5-year) plan for embracing technology and analytics in the Bank's supervisory responsibilities. ${ }^{\mathrm{z}}$ In Asia, the Hong Kong Monetary Authority (HKMA), which is the central banking authority and primary regulator for the banking system in Hong Kong, has established the FinTech Facilitation Office (FFO) for similar objectives as the OCC's Office of Innovation. Specifically, they are charged with finding the right balance of risk and reward in technological innovation in Hong Kong so that banks and FinTech companies can develop new products but with proper safeguards in place for consumers and financial stability. FCA and the BoE are working on providing regulatory guidance on FinTech innovation in the United Kingdom. As we will discuss below, the FCA launched a program in 2018 called Project Innovate. More recently, the BoE has discussed the ramping up their use of more sophisticated technologies and data analytics, noting that banks in the United Kingdom are becoming more digital and investing more heavily in AI than ever before with the trend expected to continue. ${ }^{\text {aa }}$

\footnotetext{
x https://www.occ.treas.gov/about/who-we-are/organizations/office-of-innovation/index-office-ofinnovation.html.

y https://occ.gov/topics/responsible-innovation/index-innovation.html.

${ }^{\mathrm{z}}$ https://www.bis.org/about/innovation_bis_2025/index.htm.

aa For more details, please see Carney, Mark "A Platform for Innovation" Speech delivered at the Innovate Finance Global Summit, London (April 29, 2019): https://www.bankofengland.co.uk/-/media/boe/files/ speech/2019/a-platform-for-innovation-remarks-by-mark-carney.pdf?la=en\&hash=49FE92075B4C7DBB0C7E0975CDF38488BB0A02FB.
} 
Table 3. Information on four robo-advisors in the United States.

\begin{tabular}{lccc}
\hline Firm name & Latest filing date & Number of clients & Assets under management \\
\hline Acorns Advisers, LLC & $01 / 02 / 2020$ & $2,954,677$ & $\$ 1,820,953,545$ \\
Betterment Advisors, LLC & $02 / 04 / 2020$ & 417,088 & $\$ 13,343,422,693$ \\
Sigfig Wealth Management, LLC & $03 / 28 / 2019$ & 11,154 & $\$ 465,009,824$ \\
Wealthfront Advisers, LLC & $10 / 30 / 2019$ & 245,508 & $\$ 10,556,684,339$ \\
\hline
\end{tabular}

\subsection{Regulation of activities in the financial market}

As we discussed in the Introduction, FinTech innovation is not only occurring in banking but also in derivatives and capital markets. One of the biggest influences in this space in the United States is the SEC. However, some would say that when it comes to FinTech, they have largely been reactive and not proactive. The SEC's stated mission is to "protect investors, maintain fair, orderly, and efficient markets, and facilitate capital formation." To that end, the SEC has been involved in conversations regarding robo-advisors, equity crowdfunding, and most recently cryptocurrencies and initial coin offerings (ICOs).

When it comes to robo-advisers, most are already and have been registered as investment advisors (RIAs). ${ }^{\text {bb }}$ Table 3 presents information on the latest filing dates, number of clients, and assets under management of four different robo-advisors in the United States for individual clients only (i.e. does not include high net worth individuals, pensions/profit-sharing plans, charitable organizations, corporate entities, etc.). This table shows that a substantial number of retail investors have provided a significant amount of money to robo-advisors for investment management.

In February 2017, the SEC put out an "Investor Bulletin" and issued new guidance on robo-advisers, which was built on the "Investor Alert" for automated investment tools released in May 2015. These documents clearly stated that United States robo-advisers fall under the Investment Advisers Act of 1940 and are bound by fiduciary obligations. Despite the fact that most robo-advisers are (and were) already RIAs, the SEC has additional disclosures and considerations, unique to roboadvisers' business model, including providing investors with information about the types of algorithms that are utilized and in what capacity; what overrides are in place and the extent to which human involvement and oversight; model governance standards; explanation of fees; cybersecurity; and data management (i.e. how client information is used and disclosed).

Equity crowdfunding is another part of FinTech in which the SEC has been involved in regulating. In Fall 2015, the SEC put into place Regulation Crowdfunding (or Reg CF). ${ }^{c c}$ As equity crowdfunding is an alternative to issuing stock for a firm to raise capital, Reg CF specifies the requirements for issuers (including

\footnotetext{
bb One can go to https://adviserinfo.sec.gov and search for individual robo-advisor's Form ADV, which contains detailed information about the number of accounts and assets under management.

${ }^{\mathrm{cc}}$ More formally: Title 17, Chapter II, Part 227.
} 
disclosures and reporting), requirements for intermediaries who are involved, and the regulation and registration of funding portals. The Jumpstart Our Business Startup (JOBS) Act passed by Congress in 2012 and signed by President Obama led the way for Reg CF. There are, however, exemptions from having to register capital raising for equity crowdfunding platforms, which present both opportunities and risks. The opportunity is that firms that otherwise would not be able to raise capital through an IPO issuance can tap equity investors through the crowdfunding platforms. However, the risk is that in a market already riddled with information asymmetry and misalignment of incentives, exemptions from registration may potentially amplify problems associated with a lack of transparency (see, e.g. Afterman 2016).

As the primary regulator for capital markets in the United States, the SEC is also involved in regulating cryptocurrencies and ICOs. Cryptocurrencies such as Bitcoin and StableCoin are increasingly viewed as an alternative asset class in the post-crisis era. The SEC has recognized the regulatory issues related to ICOs and has made the following comment on their website: "Companies and individuals are increasingly considering ICOs as a way to raise capital or participate in investment opportunities. While these digital assets and the technology behind them may present a new and efficient means for carrying out financial transactions, they also bring an increased risk of fraud and manipulation because the markets for these assets are less regulated than traditional capital markets." dd

The SEC uses the so-called Howey test, cleared by Supreme Court in 1946, to decide whether U.S. federal securities laws apply to a particular ICO. The Howey test comprises three elements: (i) The investment of money; (ii) common enterprise; and (iii) reasonable expectation of profit derived from the efforts of others. The first two elements are usually satisfied by digital assets, and the main issue of Howey test is to determine whether a purchaser may reasonably expect to realize returns due to the effort of Active Participants, e.g. sponsor, promoter, or a third party. ${ }^{\text {ee }}$ This third test is not met for Bitcoin so that Bitcoin is not a security. However, certain ICOs may be considered as securities offerings and fall under SEC's jurisdiction of enforcing the federal securities laws. ${ }^{\mathrm{ff}}$

When it comes to derivative securities, the SEC has limited (or no) supervisory and enforcement responsibilities. ${ }^{\text {gg }}$ The primary derivatives market regulator in the United States is the Commodities Futures and Trade Commission (CFTC). In May 2017, the CFTC launched an initiative called LabCFTC. The initiative was the

dd https://www.sec.gov/ICO/.

ee Please refer to the following framework by SEO to determine whether an ICO token is a security or not: https://www.sec.gov/files/dlt-framework.pdf.

ff Please refer to the following link for more details: https://cointelegraph.com/news/sec-if-bitcoin-was-asecurity-it-would-raise-substantial-issues.

gg One gray area that was mostly cleared up by the Dodd-Frank Act is the swaps market. Under the Dodd-Frank Act, the SEC is charged with regulating securities-based swaps, including credit default swaps (CDS) and equity swaps, while the CFTC regulates all other swaps, including interest rate swaps, commodity-linked swaps, and FX swaps. Both the SEC and CFTC have joint regulation of "mixed swaps" which are defined under 15 U.S.C. $78 \mathrm{c}(\mathrm{a})(68)(\mathrm{D})$. 


\section{T. J. Chemmanur et al.}

brainchild of then-commissioner J. Christopher Giancarlo, who had the goal of making the CFTC a "21st century regulator" both in terms of how it regulates (using data analytics and new technologies) as well as when they regulate (with the blockchain technology potentially revolutionizing derivatives settlement and clearing). Members of LabCFTC are actively involved in engagement and outreach which includes interacting with members of the FinTech community. They also develop new analytical tools, data sets for market surveillance, and cutting edge technology as a resource for the Commission. As for international cooperation, a press release was sent out on February 20, 2018, announcing a collaborative partnership between LabCFTC and the FCA's Project Innovate.

\section{The Decision to Buy Versus to Build New Financial Technologies}

As we briefly mentioned in Sec. 4, in addition to deciding whether or not to patent innovation that is developed in-house, financial institutions and FinTech companies also need to decide whether to develop new technologies in-house via R\&D efforts or to license them from other FinTech companies or to buy a new technology outright through the acquisition of a startup.

Such a "build or buy" question has been examined extensively in the finance, innovation, and economics literature under various contexts other than FinTech, and an understanding of this literature may be essential in answering this question in the FinTech context as well. Capron \& Mitchell (2004) discuss the factors that determine whether firms are likely to develop new capabilities in-house or whether they source it externally. They argue that three factors play a role in internal development versus external sourcing. They are (i) transaction-based attributes, i.e. contractual hazard which inhibit firm's ability to purchase contracts, negotiate or manage alliances, and undertake acquisitions; (ii) strategic gap, which is the gap between firm's existing knowledge attributes and the desired knowledge attributes; and (iii) internal legitimacy, which is a behavioral explanation highlighting the psychological or social costs involved in altering firm's habits. Using a theoretical model, Bourreau \& Doğan (2006) discuss the "build versus buy" decisions in telecommunication sectors and argue that the absence of regulations encourages incumbents to deter the entry of new entrants through leasing, thereby ensuring that new entrants have to choose expensive "build" strategy to enter. Gallini (1984) argues that the incumbents deter entrants to come up with breakthrough innovation that may hurt the incumbents, by sharing their (incumbents') technology with new entrants via licensing. In her model, firms are encouraged to enter the product market while deterred from $R \& D$ activities at the same time by making rights to lower-cost technologies easily accessible.

Using a Cournot oligopoly model, McCardle \& Viswanathan (1994) discuss the choice between direct entry and acquisition made by new entrants. They argue that entrants will acquire incumbents in case of higher costs to entry, while they prefer direct entry in case of lower entry cost barriers. Phillips \& Zhdanov (2013) build a 
Table 4. The distribution of the current status of various FinTech start-up firms.

\begin{tabular}{lccc}
\hline Status & Frequency & Percent & Cumulative \\
\hline Acquired & 230 & 17.57 & 17.57 \\
Inactive & 40 & 3.06 & 20.63 \\
Private & 1018 & 77.77 & 98.4 \\
Public & 21 & 1.6 & 100 \\
\hline
\end{tabular}

theoretical model to examine how the market for mergers and acquisitions affects the "build versus buy" decisions on R\&D spending and innovation. They show that large firms find it expensive to participate in $R \& D$ activities compared to acquiring innovation through acquisition in an active mergers and acquisitions market. Further, an active mergers and acquisitions market gives bargaining power to small firms, encouraging them to engage in innovation activities and increase their probability to get acquired.

FinTech firms may also experience trade-offs similar to those discussed in the above literature in terms of developing new products or technologies in-house versus accessing them through acquisitions (build or buy). We show in Table 4 that 230 (17.54\%) of the 1309 U.S.-based FinTech start-ups are eventually acquired. Further, we find that 52 of the 230 acquired firms $(22.6 \%)$ had at least one patent at the time of acquisition. This may suggest a phenomenon similar to that discussed by Phillips \& Zhdanov (2013) that FinTech start-ups are engaged in innovation activities and are getting their payoffs for their innovation through their future acquisitions by established firms.

For FinTech firms, we observe many instances of the above trade-offs in play, such as in the robo-advisory space. For example, the startup Wealthfront develops its financial advisory technology in-house whereas the 2015 acquisition of FutureAdvisor by BlackRock is an example of a new financial advisory technology being bought through an M\&A deal. Similarly, the strategic decisions of build-versus-buy occurred within the digital wealth management space as well. Incumbents such as Vanguard and Fidelity now have their in-house robo-advisory services, while Capital One Financial acquired United Income in 2019, an innovative data-driven wealth management company. The former is an example of new technology being built through the firm's own R\&D, whereas the latter is an example of an acquisition of new technology by an asset management powerhouse.

\section{Conclusion}

In this article, we have reviewed recent developments in FinTech and discussed how FinTech has affected and how it is likely to continue to affect the financial service industries. We began with an overview of what FinTech is and why it has become an important growth industry in the financial services area and therefore an important 


\section{T. J. Chemmanur et al.}

research topic in finance. In the next section, we reviewed some of the academic literature in the FinTech area. In the subsequent section, we used data from the Venture Scanner database to characterize the financing of FinTech startups, especially by venture capital firms. In the following section, we used FinTech data from Venture Scanner and patenting data from the USPTO to characterize innovation by FinTech firms and compared it to innovation by incumbent financial intermediaries. In the next section, we moved on to discuss potential sources of value creation by FinTech start-up firms relative to existing incumbent firms: we argued that in developed economies like the United States, an important source of value creation arose from FinTech startups being able to provide a superior CX relative to that provided by incumbent firms; in contrast, in less developed (emerging) markets, perhaps the most important source of value creation by FinTech firms came from providing banking services to large sections of the population that have been left unbanked by traditional intermediaries. In the following section, we discussed the regulatory environment facing FinTech firms, in their banking as well as in their financial market activities. In the penultimate section, we analyzed the buy-versus-build decision facing firms choosing to enter the FinTech sector and discussed the trade-offs that may drive such decisions in practice.

As for the future of FinTech, we expect that FinTech services will become ubiquitous in near future with both incumbents (traditional banks, wealth management services, and others) and FinTech startups offering a wide spectrum of services, including both traditional and Fintech services. They will either develop such capabilities in-house or will acquire smaller FinTech firms. We also expect some FinTech firms offering services provided by traditional intermediaries, e.g. we expect many more FinTech firms to apply for banking licenses. We also expect tech giants like Google, Amazon, Facebook, and others to participate more actively in the FinTech space. For example, Google and Apple have already offered digital wallet services to consumers across the world. Amazon Pay, launched in 2007, has evolved into digital wallet for consumers and payments networks for merchants. Facebook-owned WhatsApp has acquired licenses from the Indian authorities for their digital payment system. Given the scale of growth of FinTech firms in Asia and Europe, it is likely that the next big breakthrough in FinTech will come from FinTech firms operating in countries in Asia or Europe rather than from FinTech firms in the United States. It is also likely that in developing countries, FinTech startups will make great strides in providing banking services to large sections of the population currently left unbanked by traditional financial intermediaries.

\section{Acknowledgment}

We acknowledge financial support from a 2018 Kauffman Foundation Knowledge Challenge Grant. For helpful comments and suggestions, we thank Onur Bayar, Manish Gupta, Karen Simonyan, Xiang Zheng, Yu Wang, Jiajie Xu, Jingxuan 
Zhang, Yuxin $\mathrm{Wu}$, two anonymous referees, and Santiago Carbo-Valverde (Editor). All remaining errors or omissions remain our own responsibility.

\section{References}

J. Abadi \& M. Brunnermeier (2018). Blockchain economics. NBER working paper, National Bureau of Economic Research.

A. B. Afterman (2016). Equity crowdfunding: The good, the bad, and the potentially ugly, The CPA Journal 86, 66-67.

D. W. Arner, J. Barberis \& R. P. Buckley (2015). The evolution of Fintech: A new post-crisis paradigm, Georgetown Journal of International Law 47, 1271.

J. Bena \& K. Li (2014). Corporate innovations and mergers and acquisitions, The Journal of Finance 69, 1923-1960.

P. Berkmen, K. Beaton, D. Gershenson, J. Arze del Granado, K. Ishi, M. Kim, E. Kopp \& M. V. Rousset (2019). Fintech in Latin America and the Caribbean: Stocktaking. IMF working paper, International Monetary Fund.

S. Bernstein, X. Giroud \& R. R. Townsend (2016). The impact of venture capital monitoring, The Journal of Finance 71, 1591-1622.

J. Bessen \& E. Maskin (2009). Sequential innovation, patents, and imitation, The RAND Journal of Economics 40, 611-635.

B. Biais, C. Bisiere, M. Bouvard \& C. Casamatta (2019). The blockchain folk theorem, The Review of Financial Studies 32, 1662-1715.

M. Bourreau \& P. Doğan (2006). "Build-or-buy" strategies in the local loop, American Economic Review 96, 72-76.

G. Buchak, G. Matvos, T. Piskorski \& A. Seru (2018). Fintech, regulatory arbitrage, and the rise of shadow banks, Journal of Financial Economics 130, 453-483.

O. Canuto (2020). How Latin America can make Fintech a priority. Americas Quarterly.

L. Capron \& W. Mitchell (2004). Where firms change: Internal development versus external capability sourcing in the global telecommunications industry, European Management Review 1, 157-174.

T. J. Chemmanur, E. Loutskina \& X. Tian (2014). Corporate venture capital, value creation, and innovation, The Review of Financial Studies 27, 2434-2473.

M. A. Chen, Q. Wu \& B. Yang (2019). How valuable is FinTech innovation? The Review of Financial Studies 32, 2062-2106.

J. Chiu \& T. V. Koeppl (2019). Blockchain-based settlement for asset trading, The Review of Financial Studies 32, 1716-1753.

L. W. Cong \& Z. He (2019). Blockchain disruption and smart contracts, The Review of Financial Studies 32, 1754-1797.

F. D'Acunto, N. Prabhala \& A. G. Rossi (2019). The promises and pitfalls of robo-advising, The Review of Financial Studies 32, 1983-2020.

J. Duarte, S. Siegel \& L. Young (2012). Trust and credit: The role of appearance in peer-topeer lending, The Review of Financial Studies 25, 2455-2484.

F. J. Fabozzi (2016). Entrepreneurial Finance and Accounting for High-Tech Companies. Cambridge, MA: The MIT Press.

S. Foley, J. R. Karlsen \& T. J. Putninņš (2019). Sex, drugs, and bitcoin: How much illegal activity is financed through cryptocurrencies? The Review of Financial Studies 32, $1798-1853$.

A. Fuster, M. Plosser, P. Schnabl \& J. Vickery (2019). The role of technology in mortgage lending, The Review of Financial Studies 32, 1854-1899. 


\section{T. J. Chemmanur et al.}

N. T. Gallini (1984). Deterrence by market sharing: A strategic incentive for licensing, The American Economic Review 74, 931-941.

P. Gomber, R. J. Kauffman, C. Parker \& B. W. Weber (2018). On the Fintech revolution: Interpreting the forces of innovation, disruption, and transformation in financial services, Journal of Management Information Systems 35, 220-265.

J. M. Griffin \& A. Shams (2019). Is bitcoin really un-tethered? Working paper, University of Texas at Austin.

A. Hertzberg, A. Liberman \& D. Paravisini (2018). Screening on loan terms: Evidence from maturity choice in consumer credit, The Review of Financial Studies 31, 3532-3567.

M. B. Imerman \& F. J. Fabozzi (2020). Cashing in on innovation: A taxonomy of FinTech, Journal of Asset Management 21, 167-177.

A. B. Jaffe (1986). Technological opportunity and spillovers of R\&D: Evidence from firms' patents, profits and market value. Working paper, National Bureau of Economic Research.

J. Jagtiani \& C. Lemieux (2019). The roles of alternative data and machine learning in Fintech lending: Evidence from the LendingClub consumer platform, Financial Management 48, 1009-1029.

S. Kortum \& J. Lerner (2000). Assessing the contribution of venture capital to innovation, The RAND Journal of Economics 31, 674-692.

J. Lerner, M. Sorensen \& P. Strömberg (2011). Private equity and long-run investment: The case of innovation, The Journal of Finance 66, 445-477.

E. Mansfield (1986). Patents and innovation: An empirical study, Management Science 32, 173-181.

K. F. McCardle \& S. Viswanathan (1994). The direct entry versus takeover decision and stock price performance around takeovers, Journal of Business 67, 1-43.

T. Neudecker \& H. Hartenstein (2019). Short paper: An empirical analysis of blockchain forks in bitcoin. In: Financial Cryptography and Data Security ( I. Goldberg and T. Moore, eds.), 84-92. Cham: Springer.

T. Philippon (2016). The FinTech opportunity. Working paper, National Bureau of Economic Research.

G. M. Phillips \& A. Zhdanov (2013). R\&D and the incentives from merger and acquisition activity, The Review of Financial Studies 26, 34-78.

A. Rossi \& S. Utkus (2019). The needs and wants in financial advice: Humans versus roboadvising. Working paper, Georgetown University.

S. Samila \& O. Sorenson (2011). Venture capital, entrepreneurship, and economic growth, The Review of Economics and Statistics 93, 338-349.

J. Schmookler (1954). The level of inventive activity, The Review of Economics and Statistics 36, 183-190.

J. Schmookler \& O. Brownlee (1962). Determinants of inventive activity, The American Economic Review 52, 165-176.

S. Scotchmer (1991). Standing on the shoulders of giants: Cumulative research and the patent law, Journal of Economic Perspectives 5, 29-41.

A. Seru (2014). Firm boundaries matter: Evidence from conglomerates and R\&D activity, Journal of Financial Economics 111, 381-405.

S. Srinivasan (2018). Do weaker patents induce greater research investments? Working paper, Northwestern University.

H. Tang (2019). Peer-to-peer lenders versus banks: Substitutes or complements? The Review of Financial Studies 32, 1900-1938.

A. V. Thakor (2019). Fintech and banking: What do we know? Journal of Financial Intermediation 41, 100833. 
X. Tian \& T. Y. Wang (2014). Tolerance for failure and corporate innovation, The Review of Financial Studies 27, 211-255.

B. Vallee \& Y. Zeng (2019). Marketplace lending: A new banking paradigm? The Review of Financial Studies 32, 1939-1982.

L. D. Wall (2018). Some financial regulatory implications of artificial intelligence, Journal of Economics and Business 100, 55-63.

A. Zacharakis \& J. Muller (2016). Crowdfunding: A tale of two campaigns. Babson College Case Study. 